\title{
The impact of minimum wages on informal and formal labor market outcomes: evidence from Indonesia
}

\author{
Maike Hohberg and Jann Lay ${ }^{*}$
}

\author{
* Correspondence: \\ jann.lay@giga-hamburg.de \\ GIGA German Institute of Global \\ and Area Studies and University of \\ Goettingen, Neuer Jungfernstieg 21, \\ 20354 Hamburg, Germany
}

\begin{abstract}
This paper studies the effects of minimum wages on informal and formal sector wages and employment in Indonesia between 1997 and 2007. Applying fixed-effects methods, the estimates suggest that minimum wages have a significant positive effect on formal sector wages, while there are no spillover effects on informal workers. Regarding employment, we find no statistically significant negative effects of minimum wages on the probability of being formally employed. These findings suggest that employers use adjustment channels other than employment or that effects such as a demand stimulus on a local level outweigh the possible negative employment effects.

Jel codes: J08, J46

Keywords: Minimum wages; Employment effects; Informal sector; Wage spillover effects
\end{abstract}

\section{Introduction}

Due to limited fiscal resources, minimum wages in developing countries are a possible instrument to allow workers a decent standard of living. Yet, the effectiveness of this instrument may be limited because of the dual labor market structure of most developing economies with a formal sector effectively covered by labor market policies, such as the minimum wage, and a large informal sector where the minimum wage law does not apply. Since a large share of the poorest individuals work in the informal sector, minimum wage policy might not help to increase the incomes of the working poor (Lustig \& McLeod 1997), unless there are spillover effects on the informal sector. In fact, informal sector wages may even be depressed by a minimum wage policy if an associated decline in formal sector employment were to cause an increase in informal sector employment and a corresponding decline in informal sector wages.

This paper adds to the debate on the effects of minimum wages in developing countries in general, and Indonesia specifically, by analyzing the impacts of the minimum wage on formal and informal wages and employment, hence also examining possible spillover effects on the uncovered sector. For this purpose, we exploit three panel waves (1997, 2000, and 2007) of the Indonesian Family Life Survey (IFLS) by estimating fixed-effects models on an individual level. Minimum wages in Indonesia are

(c) 2015 Hohberg and Lay. Open Access This article is distributed under the terms of the Creative Commons Attribution 4.0 International License (http://creativecommons.org/licenses/by/4.0/), which permits unrestricted use, distribution, and reproduction in any medium, provided you give appropriate credit to the original author(s) and the source, provide a link to the Creative Commons license, and indicate if changes were made. 
intended to cover essential living needs and are annually set at the provincial level according to living expenses and are thus exposed to variation across province and time (Rama 2001). For 2015, the average of the established monthly minimum wage in 33 provinces amounts to 1,702,230 Rp, which corresponds to about 126 current US Dollars (Wage Indicator Network 2015). The minimum wage policy in Indonesia is subject to fierce public debates as witnessed by the media's attention to protesters demanding a higher minimum wage and employers warning of potential job losses due to higher labor cost (for example Vaswani 2013 for BBC, Al Jazeera 2013, and Purnomo 2014 for Bloomberg).

The remainder of the paper is structured as follows: Section 2 reviews the literature on minimum wages in developing countries with a focus on Indonesia. In Section 3 we provide some background information on minimum wage policies in Indonesia and the economic context. We then briefly present a conceptual framework of minimum wages. Section 4 describes the dataset. The empirical model and strategy are set up in Section 5. Section 6 presents estimation results, and Section 7 concludes.

\section{Theory and literature review}

In a competitive labor market model, a minimum wage set above equilibrium causes a decrease in firms' labor demand and displaces some workers from their jobs, thereby generating unemployment. This may especially affect low-skilled workers with a marginal product below the minimum wage rate. Moreover, the higher wage may encourage other individuals whose reservation wage is above the initial equilibrium and below the new minimum wage to participate in the labor force. This extra labor supply will not be matched by labor demand and hence contributes to the unemployment rate. ${ }^{1}$ In contrast to the standard model's predictions, introducing a minimum wage in a market with imperfections can lead to an increase in employment. Such settings include, for example, a monopsonistic labor market (see, e.g., Stigler 1946, Machin \& Manning 1994, and Dickens et al. 1999) and shirking (Shapiro \& Stiglitz 1984). Relating minimum wages to human capital theory, minimum wages can encourage firms to sponsor training for their workers (Acemoglu \& Pischke 1999) or give workers an incentive to invest in their skills in order to avoid unemployment induced by a minimum wage (Cahuc \& Michel 1996). In consequence, these investments enhance growth and thus employment.

While these effects may be relevant to labor markets in both developed and developing countries, a large fraction of the workforce is self-employed or works as unpaid family workers in micro and small firms in many developing countries. For these "uncovered" or "informal" groups, ${ }^{2}$ minimum wage legislation typically does not apply. This situation is captured by dual sector models, such as the early one by Welch (1974) that includes a sector effectively covered by the minimum wage law and an uncovered sector/informal sector where the policy does not apply. In this model, prior to the minimum wage, there is an initial equilibrium at the competitive wage rate in both sectors. Introducing the minimum wage in the formal sector decreases firms' labor demand and reduces formal sector employment. Displaced workers move into the informal sector, thereby shifting the labor supply curve upwards, which leads to a decrease in wages and an increase in employment in the informal sector. 
Welch's model was extended by Mincer (1976) and Gramlich (1976) who introduced the concept of "queuing for formal sector jobs" into the model. By allowing for queuing, uncovered sector workers can quit their jobs to look for formal sector employment (while they are unemployed) which would lower labor supply and increase wages in the informal sector. Some individuals may now find it more attractive to work in the informal sector than to wait for a covered sector job. This migration into and out of the covered and uncovered sector continues as long as there is a difference in the expected wages in both sectors. ${ }^{3}$

These brief theoretical considerations yield predictions that have been subject to a number of empirical studies and that we will examine empirically for the Indonesian case. First, wages should increase in the covered sector if a minimum wage is introduced or increases. Second, (higher) minimum wages increase the probability of losing a job in the covered sector. With regard to the uncovered sector, Welch's model predicts that wages fall while the model extensions by Mincer and Gramlich yield ambiguous wage effects and migration flows from one sector to the other, which are highly dependent on a set of specific conditions (e.g., the minimum wage rates, wage elasticities of labor supply and demand). Whether wages in the uncovered sector rise or fall is hence theoretically unclear.

The ambiguous predictions of theoretical models are mirrored in the empirical literature. Though the literature shows that minimum wages do indeed increase formal sector wages, the evidence for informal sector wages and employment effects is mixed. Most of the studies analyzing the impact of minimum wages on wages and employment in both the formal and informal sector use data from Latin America. For example, Maloney \& Nuñez Mendez (2004) report a positive wage effect of minimum wages for the formal sector in Colombia and a negative employment effect for both formal sector workers and the self-employed. Positive wage and negative employment effects are also found by Gindling \& Terrell (2007) for Costa Rica's formal sector. However, they find no effects for the uncovered sector. For the case of Nicaragua, Alaniz et al. (2011) show that an increase in minimum wages lowers employment and increases wages only of those private covered sector workers who earned around the minimum wage before the minimum wage increase. For Brazil, Fajnzylber (2001) finds positive wage and negative employment effects. Surprisingly, the employment effects are stronger in the informal sector. Similarly, Lemos (2004a, 2004b) finds negative but small employment effects for both sectors between 1982 and 2000 but no statistically significant employment effect when extending the dataset to 2004 (Lemos 2009).

Studies on developing countries outside Latin America are comparatively fewer in number. For instance, Dinkelman \& Ranchhod (2012) study the effects of extending minimum wage coverage to domestic workers in South Africa. They find that introducing the minimum wage resulted in a wage increase but did not change the probability of job loss for domestic workers. Contrarily, Hertz (2005) finds a decrease in employment for the same sector in the same country. In addition to the domestic sector, Bhorat et al. (2013) include retail, forestry, taxi, and security in their study. They find no clear evidence for employment effects but positive wage effects for all sectors except forestry.

There is also some previous empirical evidence for the case of Indonesia. Using a repeated cross-sectional labor force survey (Sakernas) pooled at the provincial level, Rama (2001) finds that doubling the minimum wage in the early 1990s led to an 
increase in formal average wages of 5 to $15 \%$ and a decrease in urban wage employment of 0 to 5\%. Extending Rama's study, Islam \& Nazara (2000) also find negative effects on formal employment, and Suryahadi et al. (2003) report negative impacts on overall urban formal employment; yet these effects are positive for white collar workers. Del Carpio et al. (2012) argue that using provincial data might lead to an endogeneity bias since the local governments participating in the minimum wage setting process take the labor market conditions in their provinces into consideration. Hence, they use a firm-level dataset Survei Industri (SI) to analyze the formal manufacturing sector and report negative employment effects for small but not for large firms with a negative overall impact. Firm-level data was also used by Harrison \& Scorse (2010), who find that more than doubling the minimum wages had increased wages for unskilled production workers but decreased employment of them. Alatas \& Cameron (2008) apply a difference-in-difference approach adapted from Card \& Krueger (1994) and match similar firms from Botabek and Jakarta. Like Del Carpio et al., they report statistically significant and negative effects only for small firms that, however, become insignificant when reducing the control group to firms situated on the border of the two regions. While most studies on Indonesia focus on formal sector employment, there are only a few that consider informality as well. Comola \& de Mello (2011), using Sakernas data and data from the National Socio-Economic Survey (Susenas) on district level, find that an increase in informal employment more than compensates for job losses in the formal sector. Similar employment effects are found by The World Bank (2010), where the authors use Sakernas as well and report a shift from the formal to the informal sector, although minimum wages do not appear to change the overall employment level. Magruder (2013) opposes these results by observing that an increase in minimum wages in one district relative to its adjacent districts leads to more employment in the formal sector and to a decrease in informality. Finally, Chun \& Khor (2010) use the IFLS and apply an estimation strategy developed by Neumark et al. (2004) which includes dummies in order to indicate an individual's wage distribution position. While they find positive wage and negative employment effects for individuals at the lower end of the wage distribution in the formal sector, they do not observe such effects in the informal sector.

As a result, from the literature survey we conclude the following. First, minimum wages seem to have a positive overall effect on average wages, with a higher impact on workers earning below or around the (new) minimum wage. Second, employment effects are unclear even for the same country under study. Most studies tend to find negative effects on formal employment of a relatively small order of magnitude. Hardly any unambiguous pattern emerges with regard to the effects of minimum wages on the informal labor market segment. The literature to date neither gives a clear indication that informal sector wages are depressed because of labor being released from formal sectors, nor is there any systematic evidence on wage spillover effects, that is, if minimum wages also raise informal wages. This paper contributes to the debate by looking into the effects on minimum wages on both formal and informal labor market outcomes. Almost all of the studies analyzing the case of Indonesia use datasets (Susenas, Sakernas, SI) that do not provide information on wages of individuals working in the informal sector. Instead, we use a different dataset - the IFLS - that reports labor income in the informal sector. By using individual-level data, we avoid the potential endogeneity bias 
which estimations on a provincial level suffer from and the panel dimension allows controlling for individual fixed effects. To our knowledge, only Chun \& Khor (2010) have used the IFLS on an individual level to analyze minimum wage effects in Indonesia, but their analysis differs in terms of panel waves used and methodology applied.

\section{Background on minimum wages in Indonesia}

The first minimum wage in Indonesia was already introduced in 1956, followed by a national wage council established in 1969 and minimum wage legislation implemented in the early 1970s (Saget 2008). However, until the late 1980s, minimum wages had more a symbolic character since they were neither binding nor enforced (Pratomo 2012). ${ }^{4}$ Under increasing pressure from domestic and international groups against low wages and labor standards in the growing economy, the Indonesian government implemented new minimum wage legislation in 1989 that states that minimum wages have to be based on minimum physical needs, ${ }^{5}$ local costs of living, and labor market conditions (Rama 2001). In 2001, in line with a national devolution policy, the responsibility for minimum wage setting was given to provincial governments. That is, district wage commissions calculate annual subsistence living needs based on annual survey data and prepare a recommendation for a district minimum wage (Widarti 2006). Based on these district-level recommendations, the governor and the provincial wage council elaborate a recommendation for a provincial minimum wage before the governor announces the final rate.

The minimum wage legally applies to all workers/laborers (every person who works for a wage or other forms of remuneration) (International Labour Organisation ILO 2004), leaving the self-employed and unpaid family members uncovered. Given that they account for around half of the workers in our dataset, these groups have to be taken into account when analyzing labor market effects of the minimum wage policy.

Figure 1 shows minimum wage growth in nominal and real terms. During the first half of the 1990s, nominal wages tripled and more than doubled in real terms. The Asian crisis in 1998 caused a rise in prices and hence a decline in real minimum wages (Magruder 2013), but they reemerged as a key social policy instrument soon after the slump. Since 2001, real and nominal minimum wages have been steadily increasing and experienced only a short stagnation in real terms at the beginning of the international crisis $2007 / 2008$, which is however hardly visible in the figure.

To get a rough idea of the levels the minimum wage has reached within our period of analysis, 1997-2007, the ratio of the minimum to the median wage across countries is an interesting indicator. In 2004, minimum wages varied between 114 and 225 current Int. \$ monthly (33-74 current USD) (Saget 2008), and the national average almost reached $65 \%$ of the median wage in Indonesia (Comola \& de Mello 2011). France, an advanced economy with a relatively high minimum wage, had in the same year a real hourly minimum wage of 9.5 current Int.\$ (OECD 2015b and authors' exchange rate conversions) corresponding to $66 \%$ of the median hourly wage-higher than in almost all other OECD countries except for Turkey (OECD 2015a). Comparing Indonesia's minimum wage rate with seven other Asian countries that are similar in terms of economic development, Manning (2003) finds that the ratio of PPP adjusted per capita income and minimum wage rates in 2002 was second highest in Indonesia.

These stylized facts make Indonesia a worthwhile case study for the effects of minimum wages in a developing country: Minimum wages in Indonesia apply only to the 


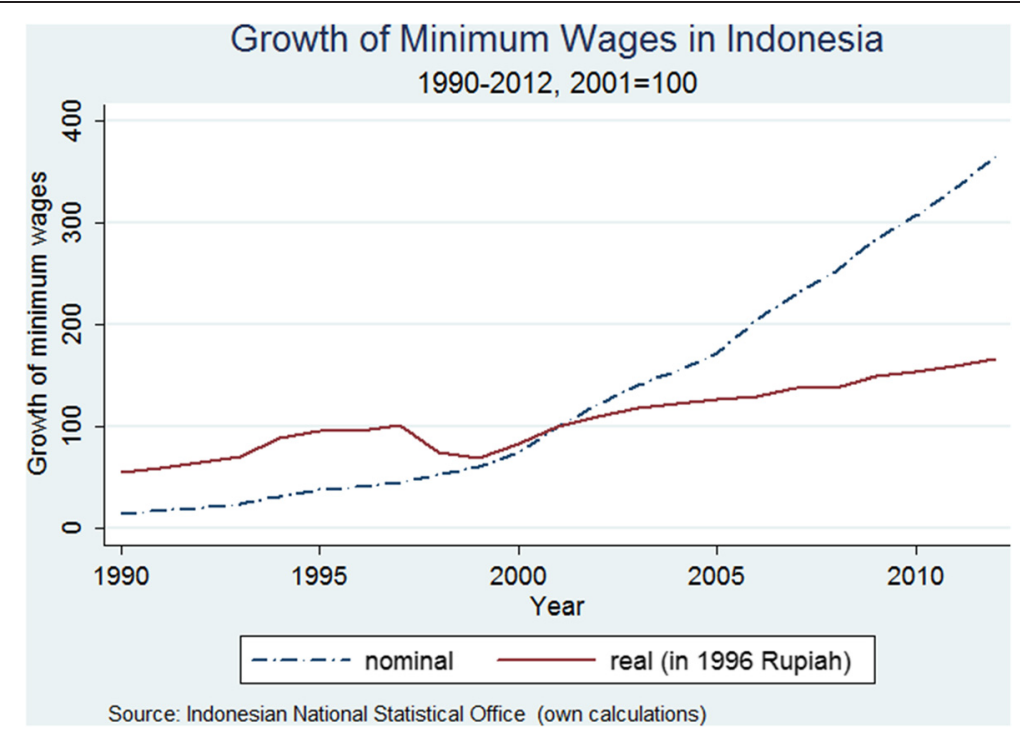

Fig. 1 Minimum Wage Growth from 1990-2012. Note: Monthly nominal and real minimum wages indexed to $2001=100$. Nominal minimum wages are the average of all provincial minimum wages and apply to workers employed in the province. Real wages are obtained by deflating by the national CPI (base year 1996)

formal sector, leaving a large sector of informal workers and self-employed uncovered. There is sufficient variation over time as minimum wages are annually set. Finally, Indonesian minimum wages are considered to be sufficiently high to provoke significant impacts on the labor market.

\section{Data and descriptive analysis}

\subsection{The dataset}

The main analysis of this paper relies on the last three waves $(1997,2000,2007)$ of the Indonesian Familiy Life Survey (IFLS), a longitudinal survey on the individual, household, and community level. Besides its extremely low attrition rate (Strauss et al. 2009), the great advantage of the IFLS compared to datasets such as Sakernas is that it includes data on labor market outcomes for the self-employed. The data set for the employment regressions includes 48,030 observations of 18,825 active or inactive individuals (excluding students and sick or retired individuals) of working age (between 15 and 60 years) who appear at least twice in adjacent survey waves. Individuals are considered "active" if they report to be employed (as self-employed, government worker, private worker, unpaid family worker, casual worker in agriculture, casual worker not in agriculture) or mention "work" as their primary activity. On the contrary, individuals are inactive if they report a primary activity other than work ${ }^{6}$ and neither report work status, or salary or profit. In addition to the classification in "active" and "inactive," the reported work status helps us to categorize active individuals into "formal" or "informal." That is, we distinguish formal from informal workers by employment type, i.e., classifying those workers as formal that are either private or government workers and as informal those workers who report "self-employed" or "unpaid family worker" as their working status. ${ }^{7,8}$ Wages for the self-employed are based on last month's reported profit. In case this is missing, last year's profit was divided by 12. In the analysis of wage effects, the dataset is restricted to individuals who report to 
be employed full-time in at least two adjacent survey waves. In the regression analysis, we exclude the top percentiles of monthly income earners to avoid that results are driven by high end salaries. We focus on full-time workers because they are targeted by minimum wages, which are announced as a monthly rate without clear guidelines on earnings of part-time workers (Rama 2001). Full-time workers are selected on the variable hours of work (working hours of 35 and above). There are only a few missing values for hours worked of those individuals that reported to be working. Even before excluding individuals due to a high age or as outliers in terms of wage, the missing values amount to less than $2 \%$. In addition, by extracting full-time workers, we seek to disentangle the effect of minimum wages on wages from the possible effect of minimum wages on working hours that also might change wages due to a transition from part- to full-time workers. ${ }^{9}$ Eventually, we end up with datasets of around of 18,000 observations with the exact number depending on if and how we include full-time workers that reported to have zero-wages in our sample (see section 5).

\subsection{Labor market structure}

Table 1 presents cross-sectional descriptives on the composition of the working-age population separately for the survey years 1997, 2000 and 2007. The share of inactive individuals has decreased from $28.0 \%$ in 1997 to $21.2 \%$ in 2007 . The majority of inactive individuals are women, with more than $80 \%$. The descriptive statistics illustrate the massive expansion of education in Indonesia. While in $199741.5 \%$ of the employed workforce did not complete primary school, this share decreased to $26.8 \%$ in 2007. At the same time, the share of workers who completed high school has increased by 6.6 percentage points between 1997 and 2007. Most workers in Indonesia are employed in the informal sector that steadily increased relative to the formal sector between 1997 and 2007 , reaching a share of $64.3 \%$ of all workers in the last survey year. Almost $70 \%$ of all workers are full-time workers. The ratios of formal and informal sector workers among full-time workers have also changed over time. While more full-time workers were formally employed in 1997 and 2000 (56.5 and 53.2\%), 57.7\% of full-time employment was informal in 2007. This raises the question whether rises in minimum wages were partly responsible for this development.

\subsection{Minimum wages and the wage distribution}

Table 2 presents descriptive statistics on both minimum wages and real wages. ${ }^{10,11}$ The average of nominal minimum wages has drastically increased, reaching 667,767 Rp per month (about 75 USD of 2007) in 2007, which is around five times the nominal minimum wage in 1997. In real terms, the total increase by around 35\% from 1997 to 2007 is more moderate. As an aftermath of the crisis in 1998, during which real minimum wages sharply decreased due to drastic price increases (Magruder 2013), real minimum wages in 2000 were still smaller than in 1997. Taking a closer look at the real wages, it seems that inequality decreased somewhat between 1997 and 2007 since wages in the top decile increased by $17 \%$ while growth in the bottom decile was $34 \%$. This goes in line with a general decrease in wage inequality observed, for example, by Chun \& Khor (2010). ${ }^{12}$ In all three years, the share of formal sector workers who earn below the minimum wage is smaller than for workers in the informal sector. For formal sector 
Table 1 Composition of working age population

\begin{tabular}{|c|c|c|c|}
\hline & 1997 & 2000 & 2007 \\
\hline Inactive & $28.0 \%$ & $21.3 \%$ & $21.2 \%$ \\
\hline average age in years & 32.7 & 32.6 & 33.7 \\
\hline male & $17.5 \%$ & $17.4 \%$ & $19.5 \%$ \\
\hline \multicolumn{4}{|l|}{ education completed } \\
\hline no school completed & $41.7 \%$ & $28.3 \%$ & $21.7 \%$ \\
\hline elementary school & $28.9 \%$ & $29.4 \%$ & $27.3 \%$ \\
\hline middle school & $13.5 \%$ & $18.6 \%$ & $21.8 \%$ \\
\hline high school & $14.6 \%$ & $20.7 \%$ & $25.2 \%$ \\
\hline higher education & $1.4 \%$ & $3.1 \%$ & $4.0 \%$ \\
\hline job searching (of inactives) & $19.0 \%$ & $7.3 \%$ & $6.7 \%$ \\
\hline Students & $10.5 \%$ & $9.8 \%$ & $10.0 \%$ \\
\hline Active & $61.5 \%$ & $68.9 \%$ & $68.8 \%$ \\
\hline average age in years & 36.2 & 36.5 & 38.0 \\
\hline male & $62.0 \%$ & $58.3 \%$ & $58.7 \%$ \\
\hline \multicolumn{4}{|l|}{ education completed } \\
\hline no school completed & $41.5 \%$ & $33.1 \%$ & $26.8 \%$ \\
\hline elementary school & $26.5 \%$ & $28.0 \%$ & $26.1 \%$ \\
\hline middle school & $11.1 \%$ & $14.0 \%$ & $15.7 \%$ \\
\hline high school & $16.5 \%$ & $18.7 \%$ & $23.1 \%$ \\
\hline higher education & $4.3 \%$ & $6.2 \%$ & $8.3 \%$ \\
\hline formal & $49.2 \%$ & $46.0 \%$ & $35.7 \%$ \\
\hline informal & $50.8 \%$ & $54.0 \%$ & $64.3 \%$ \\
\hline unpaid family workers & $20.9 \%$ & $26.2 \%$ & $23.6 \%$ \\
\hline full-time & $69.2 \%$ & $68.6 \%$ & $67.6 \%$ \\
\hline formal & $56.5 \%$ & $53.2 \%$ & $42.3 \%$ \\
\hline informal & $43.5 \%$ & $46.8 \%$ & $57.7 \%$ \\
\hline unpaid family workers & $16.9 \%$ & $20.1 \%$ & $18.2 \%$ \\
\hline
\end{tabular}

Note: These statistics are based on a panel data of overall 80,739 observations, or 39,201 individuals. The sub-population under consideration are individuals between 15 and 60 years old (71,600 observations, 36,261 individuals). These statistics are weighted using cross-sectional weights of the respective survey year provided by the IFLS in order to provide a representative sample

workers this share decreased from $40.6 \%$ to $32.2 \%$, indicating a higher compliance with the law (or a less binding minimum wage with constant compliance). Compared to 1997, in 2007 the share of informal workers earning below the minimum did not change much and remained at about $55 \%$, with a temporary decrease to $42.5 \%$ in the aftermath of the 1997 crisis. $^{13}$ Over the considered period, the development of real wages has been favorable for formal sector workers (an increase of $28 \%$ ), while informal sector wages increased by only $11 \%$. Hence, the increase in real minimum wages between 2000 and 2007 does not seem to have had a strong impact on informal wages.

To test if minimum wages are sufficiently enforced to distort the wage distribution and provoke labor market effects, Fig. 2 presents kernel densities of log wages normalized to minimum wages for formal and informal workers. As Indonesia has various levels of minimum wages, we subtract the log of real minimum wages from the log of real wages. ${ }^{14}$ Then, in Fig. 2, zero or the vertical line indicates that a worker is earning 
Table 2 Monthly minimum wage and real wages

\begin{tabular}{|c|c|c|c|}
\hline & 1997 & 2000 & 2007 \\
\hline \multicolumn{4}{|c|}{ mean minimum wage } \\
\hline nominal & $131,346 \mathrm{Rp}$ & $218,774 \mathrm{Rp}$ & $667,767 \mathrm{Rp}$ \\
\hline real & $326,737 \mathrm{Rp}$ & $272,308 \mathrm{Rp}$ & $444,745 \mathrm{Rp}$ \\
\hline \multicolumn{4}{|c|}{ mean real wage } \\
\hline all & $505,133 \mathrm{Rp}$ & $500,415 \mathrm{Rp}$ & $593,130 \mathrm{Rp}$ \\
\hline formal & $536,345 \mathrm{Rp}$ & $503,143 \mathrm{Rp}$ & $685,914 \mathrm{Rp}$ \\
\hline informal & $449,206 \mathrm{Rp}$ & $495,902 \mathrm{Rp}$ & 497,795 Rp \\
\hline \multicolumn{4}{|c|}{ mean real wage in certain deciles } \\
\hline top & $1,712,152 \mathrm{Rp}$ & $1,671,412 \mathrm{Rp}$ & $2,010,690 \mathrm{Rp}$ \\
\hline bottom & $62,731 \mathrm{Rp}$ & $66,088 \mathrm{Rp}$ & $83,945 \mathrm{Rp}$ \\
\hline \multicolumn{4}{|c|}{ share below minimum wage } \\
\hline all & $46.5 \%$ & $36.7 \%$ & $43.7 \%$ \\
\hline formal & $40.6 \%$ & $33.1 \%$ & $32.2 \%$ \\
\hline informal & $56.9 \%$ & $42.5 \%$ & $55.5 \%$ \\
\hline
\end{tabular}

Note: The subpopulation of interest is full-time workers between 15 and 60 years old who reported positive income. In each survey year; top and bottom percentile of wages are excluded as outliers. The mean of the minimum wage is a simple average over provinces in the sample, all other statistics are weighted using cross-sectional weights of the respective survey year

the minimum wage. The wages left of the vertical line are below the minimum wage, and the wages on the right-hand side are above. In case of nearly complete enforcement, we expect that only few workers earn below the minimum wage and that the graph would be truncated at the left-hand side of the vertical line. Moreover, there should be a visible spike in the distribution around the minimum wage as we would expect wage rates to cluster around the minimum wage as an anchor (from below, but possibly also from above).

Figure 2 shows that there is still a considerable share of workers earning less than the minimum wage (left to zero) in the two groups, indicating that enforcement is not complete. Yet, there is clear evidence of some degree of truncation for the group of

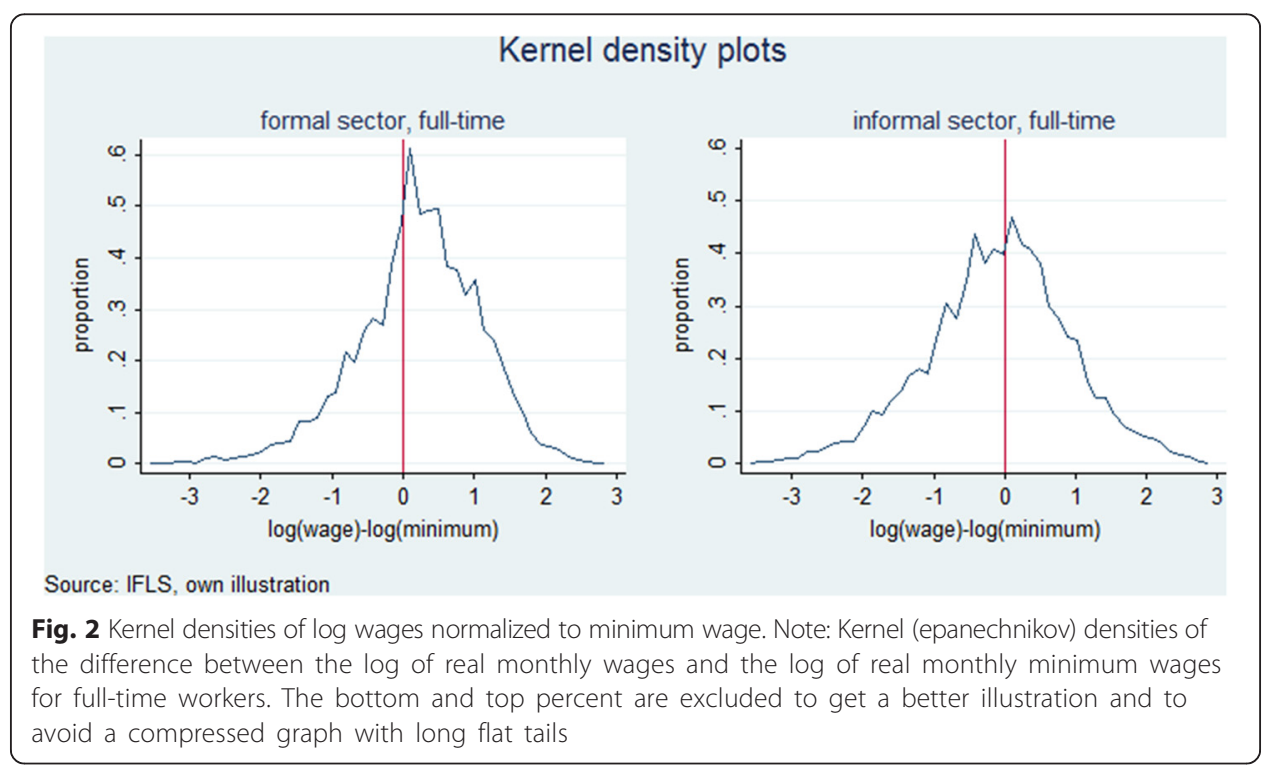


full-time formal sector workers. Furthermore, for this group the kernel density distribution shows a clear spike around zero, indicating that at least some wages are affected by the minimum wage. For informal workers the graph does not show evidence of truncation but a smaller spike in the distribution for informal fulltime workers around zero is also visible, which would mean that there may be some wage spillover effects to this group. One common explanation for spillovers is that the minimum wage is perceived as a "fair" or a benchmark wage with which workers can easily compare their own wage and therefore possibly develop some reluctance against working for wages below the minimum (Cunningham 2007). On the demand side it might be possible that employers try to prevent their workers leaving for formal sector jobs where they would get the minimum wage (ibid.).

\section{Empirical strategy}

\subsection{Estimating the effects on wages}

To examine the relationship between minimum wages and individual wages in Indonesia, we estimate how the individual wage changes after a change in minimum wage given that a worker remains employed from one period to the next. Hence, we specify the model as follows:

$$
\ln W_{i t}=\beta_{0}+\beta_{1} \ln M W_{j t}+\beta_{2} \ln \mathrm{GD} P_{j t}+\gamma X_{i t}^{\prime}+a_{i}+\delta_{t}+\varepsilon_{i t},
$$

where the explained variable is the natural logarithm of real wages of an individual $i$ at time $t$. Then, $\ln M W_{j t}$ is the $\log$ of real minimum wage that applies to the province $j$ where the worker lives in year $t$. Hence, the coefficient $\beta_{1}$ can be interpreted as the elasticity of individual real wages with respect to real minimum wages. The choice of the other regressors follows the literature (for example, Alaniz et al. 2011, Gindling \& Terrell 2005). In (1), $X_{i t}^{\prime}$ is a vector of individual specific control variables including age, gender, type of school completed, whether the individual lives in an urban area, and the sector in which the individual works. The other regressors include the log of provinces' gross domestic product (GDP) to control for province specific economic conditions, time fixed effects $\delta_{t}$ to capture year-specific influences and individual effects $a_{i} \cdot \varepsilon_{i t}$ is the idiosyncratic error term.

To estimate this model, the within-estimator is used, which can easily deal with unbalanced panels. Individual effects $a_{i}$ and other time-invariant observable characteristics (plus age ${ }^{15}$ ) are hence canceled out from the equation. Time effects, denoted by $\delta_{t}$ in Eq. (1), control for macroeconomic variables such as aggregate supply and demand, and for timing of minimum wage changes (Alaniz et al. 2011).

We made a serious attempt to take into account that "wages" for unpaid family members in informal household enterprises are not observed. To estimate the effects of the minimum wage on informal sector pay, we therefore propose three different specifications. In the first specification, we assume zero wages for unpaid family workers and use our standard log specification, i.e., family workers are not taken into account. We then estimate this equation in levels so that these workers actually enter the regression. This estimate can be thought of as a lower bound estimate on the effects of the minimum wage on informal sector pay. At least this 
estimate would capture an effect that depresses informal sector pay by increasing the number of unpaid family workers assumed to earn nothing at all. In turn, our third specification can be seen as an upper bound estimate of the effects of the minimum wage. Here, we impute a wage for unpaid family workers, and we do so in different ways to test for robustness. The first imputation procedure is based on a simple "wage regression" for all employed individuals, and we insert predicted wages into (log and level) specifications as before. The second more sophisticated imputation procedure tries to account for the heterogeneity of family enterprises. In addition to the wage equation for all employed individuals, we also estimate an income equation only for the self-employed. We then use the residual of this equation to rank the "family businesses" (with the residual being interpreted as the productivity of observed income determinants). We then assign to each unpaid family worker a residual from the observed distribution of residuals (for all employed) in accordance with the rank of the business. Simply put, we hence assume that individuals that work as unpaid family members in family businesses with high reported self-employment income are assumed to earn a higher implicit wage.

\subsection{Estimating the effects on employment}

Since the major argument against minimum wages is that they will cause job losses, we examine how employment responds to changes in the minimum wage. We use a linear probability model (LPM) with fixed effects for all workers and for formal sector workers separately, as formal employment is more likely to react to minimum wage changes. The model is specified as follows:

$$
\begin{aligned}
& W_{O R K S} S_{i t}=\beta_{0}+\beta_{1} \ln M W_{j t}+\beta_{2} \ln G D P_{j t}+\gamma X_{i t}^{\prime}+a_{i}+\delta_{t}+\varepsilon_{i t}, \\
& \text { where } W_{\text {ORKS }} \in\{0,1\}
\end{aligned}
$$

Here, the dependent variable is binary and indicates whether the individual works or not. The explanatory variables are the same as those in the previous section ${ }^{16}$ plus additional dummies for taking care of children and elderly. We use the within-estimator to transform this equation and eliminate $a_{i}$ and apply OLS on the transformed equation to get consistent estimates. Cluster-robust standard errors are used to correct for correlation within clusters and heteroskedasticity.

The simplicity of the LPM comes at costs: If an explanatory variable increases ceteris paribus by one unit, the dependent variable always changes by the same amount independent of the explanatory variable's level implying constant marginal effects. Moreover, predicted probabilities derived from the model can be greater than one or smaller than zero. However, as we am mainly interested in the sign of the minimum wage on the probability of (formal) employment, the LPM might still give a good indication of the direction of minimum wage effects.

In a second step, we combine a logit model with FE without making assumptions about the relationship between the unobserved effects $a_{i}$ and the regressors. ${ }^{17}$ In our case, this strategy implies that we will consider only those individuals who report different employment status in different survey waves. Transforming equation (2) into a conditional logit fixed effect model, yields: 
$W O R K S_{i t}=\Lambda\left(\beta_{0}+\beta_{1} \log M W_{j t}+\beta_{2} G D P_{j t}+\gamma X_{i t}^{\prime}+a_{i}+\delta_{t}+\varepsilon_{i t}\right)$,

where $W_{O R} S_{i t} \in\{0,1\}$,

where $\Lambda$ is the logistic function, and the variables remain the same as in the linear model.

By having informal work as the dependent variable we can already test whether the probability of being informally employed increases with minimum wages. Yet, combining the reference categories formal employment and unemployment into the same category is not ideal. One may argue that it has little meaning in the case that the probability of having an informal job decreases because the worker is being laid off. There is no direct model to combine a multinomial model with fixed effects as conditional maximum likelihood is not possible. Allison (2009) proposes a "hybrid model" that basically combines estimating the within and the between variations of the observed group and is able to deal with a dependent variable that has more than two categories. To implement this model, we calculate means and deviation from those means of time varying variables while time invariant variables such as gender and age at first survey wave enter as they are. Subsequently, a multinomial logit model is estimated with informal work as the base category and formal employment and not employed as comparison categories.

\section{Results}

\subsection{Wage effects}

Tables 3, 4 and 5 present results from a FE regression of the wage equation (1) for a subsample of workers that are classified as full-time workers in at least two adjacent survey waves. Our results hence only hold for those who remained full-time employed, but this is also the effect that we are interested in here; sample selection is thus not a major issue.

Table 3 shows the effects of minimum wages on wages of all full-time workers. In the remaining tables we distinguish between the formal and the informal sector, i.e., considering only workers who have not changed their formal/informal status in two adjacent survey waves. This procedure seeks to capture the "pure" wage effects in the respective sector that should not be distorted by individuals changing sectors and thereby experiencing a change in wages. For both formal and informal workers we also present the results for a subsample of individuals who earn below the minimum wage in their first year of appearance in the survey (columns 2 and 4). We expect these individuals to benefit most from the minimum wages, as they also constitute the target group of the minimum wage policy.

For all workers together, the coefficients of the minimum wage are positive and significant at least at the $5 \%$ level. Not taking zero wages into account, column (1) suggests that a $1 \%$ increase in minimum wages leads, on average, to an increase in real wages of $0.129 \%$, holding all other variables constant. With imputed wages for unpaid family workers, the estimates are slightly higher, with an increase of 0.145 (simple wage imputation) or $\mathbf{0 . 1 6 4 \%}$ (imputation accounting for heterogeneity of family businesses) and can be considered to be an upper bound estimate of the wage effects. The level specification with zero wages, which we consider as a lower bound estimate for the effect on average wages, suggests that an increase by 100 Rs in minimum wages is associated with an increase in real wages by 31.9 Rs (column 3 ). This estimate lies in between 
Table 3 Wage regression using fixed effects for all workers

\begin{tabular}{|c|c|c|c|c|c|c|c|c|}
\hline & (1) & (2) & (3) & (4) & (5) & (6) & (7) & (8) \\
\hline VARIABLES & $\log$ & $\begin{array}{l}\text { log- } \\
\text { below }\end{array}$ & level & $\begin{array}{l}\text { level- } \\
\text { below }\end{array}$ & $\begin{array}{l}\text { imput1 - } \\
\text { log }\end{array}$ & $\begin{array}{l}\text { imput1 - } \\
\text { level }\end{array}$ & $\begin{array}{l}\text { imput2 - } \\
\text { log }\end{array}$ & $\begin{array}{l}\text { imput2 - } \\
\text { level }\end{array}$ \\
\hline \multirow[t]{2}{*}{$\log M W$} & $0.129^{* *}$ & $0.328^{* * *}$ & & & $0.145^{* * *}$ & & $0.164^{* * *}$ & \\
\hline & $(0.0593)$ & (0.0998) & & & $(0.0552)$ & & $(0.0571)$ & \\
\hline \multirow[t]{2}{*}{ mw_real } & & & $0.319^{* * *}$ & $0.301^{* * *}$ & & $0.308^{* * *}$ & & $0.320^{* * *}$ \\
\hline & & & $(0.0752)$ & $(0.0841)$ & & $(0.0738)$ & & $(0.0745)$ \\
\hline \multirow{2}{*}{$\begin{array}{l}\text { log prov. } \\
\text { GDP }\end{array}$} & $0.118^{* * *}$ & $0.270^{* * *}$ & -462.6 & 48,243 & $0.143^{* * *}$ & $-1,368$ & $0.153^{* * *}$ & $-3,261$ \\
\hline & $(0.0424)$ & $(0.0797)$ & $(28,407)$ & $(42,374)$ & $(0.0404)$ & $(27,949)$ & $(0.0437)$ & $(28,983)$ \\
\hline \multirow{2}{*}{$\begin{array}{l}\text { elementary } \\
\text { school }\end{array}$} & 0.0357 & -0.0150 & 10,834 & -180.4 & 0.0626 & 10,523 & $0.0801^{*}$ & 13,549 \\
\hline & $(0.0444)$ & $(0.0737)$ & $(19,754)$ & $(23,472)$ & $(0.0412)$ & $(19,414)$ & $(0.0415)$ & $(19,176)$ \\
\hline \multirow{2}{*}{$\begin{array}{l}\text { middle } \\
\text { school }\end{array}$} & 0.0668 & 0.0833 & 31,917 & 15,971 & $0.0992^{*}$ & 37,031 & $0.115^{* *}$ & 33,885 \\
\hline & $(0.0549)$ & $(0.102)$ & $(31,208)$ & $(39,272)$ & $(0.0515)$ & $(30,522)$ & $(0.0539)$ & $(30,397)$ \\
\hline \multirow{2}{*}{$\begin{array}{l}\text { high } \\
\text { school }\end{array}$} & $0.216^{* * *}$ & $0.466^{* * *}$ & $76,022^{*}$ & $135,301^{* * *}$ & $0.242^{* * *}$ & $77,539^{*}$ & $0.246^{* * *}$ & $66,851^{*}$ \\
\hline & $(0.0682)$ & $(0.143)$ & $(41,167)$ & $(51,888)$ & $(0.0650)$ & $(40,261)$ & $(0.0694)$ & $(40,265)$ \\
\hline \multirow{2}{*}{$\begin{array}{l}\text { higher } \\
\text { educ }\end{array}$} & $0.363^{* * *}$ & $0.941^{* * *}$ & $320,516^{* * *}$ & $528,869^{* * *}$ & $0.386^{* * *}$ & $321,055^{* * *}$ & $0.391^{* * *}$ & $313,286^{* * *}$ \\
\hline & $(0.0902)$ & $(0.239)$ & $(71,297)$ & $(141,645)$ & $(0.0876)$ & $(70,374)$ & $(0.0906)$ & $(70,445)$ \\
\hline \multirow[t]{2}{*}{ urban } & $0.116^{* * *}$ & $0.158^{* * *}$ & $61,856^{* * *}$ & 23,654 & $0.0915^{* * *}$ & $63,970^{* * *}$ & $0.0907^{* * *}$ & $64,266^{* * *}$ \\
\hline & $(0.0326)$ & $(0.0551)$ & $(17,567)$ & $(18,567)$ & $(0.0302)$ & $(17,276)$ & $(0.0318)$ & $(17,818)$ \\
\hline \multirow[t]{2}{*}{2000} & 0.00297 & $0.322^{* * *}$ & 11,129 & $113,838^{* * *}$ & 0.00627 & 7,821 & -0.000519 & 7,680 \\
\hline & $(0.0198)$ & $(0.0361)$ & $(8,162)$ & $(8,786)$ & $(0.0184)$ & $(8,022)$ & $(0.0189)$ & $(8,078)$ \\
\hline \multirow[t]{2}{*}{2007} & $0.153^{* * *}$ & $0.529 * * *$ & $85,773^{* * *}$ & $182,642^{* * *}$ & $0.128^{* * *}$ & $87,089^{* * *}$ & $0.113^{* * *}$ & $86,086^{* * *}$ \\
\hline & $(0.0212)$ & $(0.0385)$ & $(12,996)$ & $(17,386)$ & $(0.0201)$ & $(12,781)$ & $(0.0210)$ & $(13,043)$ \\
\hline Observations & 16,773 & 7,200 & 19,617 & 9,613 & 18,308 & 19,617 & 18,162 & 19,617 \\
\hline $\begin{array}{l}\text { Adj. } \\
\text { R-squared }\end{array}$ & 0.051 & 0.175 & 0.050 & 0.145 & 0.046 & 0.051 & 0.048 & 0.051 \\
\hline
\end{tabular}

All specifications include sector and year dummies as control variables Robust standard errors in parentheses

${ }^{*} p<0.1,{ }^{* *} p<0.05,{ }^{* * *} p<0.01$

those obtained in the level regression using the different imputation procedures (compare to columns 6 and 8). It is hence likely that there are no strong effects of the minimum wage on average wages by driving individuals into unpaid family work. The group of workers that earned below the minimum wage at their first appearance in the survey seems to experience a higher wage increase than all workers (column 1 compared to column 2) but only when zero wages are not considered (column 3 and 4).

The positive average effect on all workers is mainly driven by the wage effects on formal sectors workers. For these workers, a $1 \%$ increase in minimum wages is associated with a $0.178 \%$ wage increase. The coefficient is highly significant and becomes much larger when considering only those formal sector workers that reported wages below the minimum wage in the first wave of appearance. For them, a $1 \%$ change in minimum wages ceteris paribus leads to $0.613 \%$ higher wages in that group. This might be an 
Table 4 Wage regression using fixed effects for formal workers

\begin{tabular}{|c|c|c|c|c|}
\hline & $(1)$ & $(2)$ & (3) & (4) \\
\hline VARIABLES & $\log$ & log- below & level & level-below \\
\hline \multirow[t]{2}{*}{$\log M W$} & $0.178^{* * *}$ & $0.613^{* * *}$ & & \\
\hline & $(0.0650)$ & $(0.150)$ & & \\
\hline \multirow[t]{2}{*}{ mw_real } & & & $0.446^{* * *}$ & $0.548^{* * *}$ \\
\hline & & & $(0.110)$ & $(0.142)$ \\
\hline \multirow[t]{2}{*}{ log prov. GDP } & $0.0770^{*}$ & 0.0970 & $-4,600$ & 5,197 \\
\hline & $(0.0450)$ & $(0.118)$ & $(42,051)$ & $(111,281)$ \\
\hline \multirow[t]{2}{*}{ elementary school } & 0.0308 & -0.000173 & 8,684 & $-25,953$ \\
\hline & $(0.0496)$ & $(0.0842)$ & $(25,509)$ & $(24,315)$ \\
\hline \multirow[t]{2}{*}{ middle school } & 0.0232 & 0.142 & 8,909 & 50,194 \\
\hline & $(0.0693)$ & $(0.135)$ & $(42,818)$ & $(69,684)$ \\
\hline \multirow[t]{2}{*}{ high school } & $0.330^{* * *}$ & $0.745^{* * *}$ & $119,712^{* *}$ & $211,456^{* * *}$ \\
\hline & $(0.0813)$ & $(0.181)$ & $(53,019)$ & $(79,081)$ \\
\hline \multirow[t]{2}{*}{ higher educ } & $0.516^{* * *}$ & $1.116^{* * *}$ & $428,126^{* * *}$ & $634,912^{* * *}$ \\
\hline & $(0.0971)$ & $(0.263)$ & $(77,021)$ & $(166,072)$ \\
\hline \multirow[t]{2}{*}{ urban } & $0.118^{* * *}$ & $0.210^{* * *}$ & $62,937^{* * *}$ & $74,486^{* *}$ \\
\hline & $(0.0344)$ & $(0.0694)$ & $(22,293)$ & $(31,506)$ \\
\hline \multirow[t]{2}{*}{2000} & -0.00955 & $0.316^{* * *}$ & 4,746 & $109,358^{* * *}$ \\
\hline & $(0.0228)$ & $(0.0591)$ & $(11,163)$ & $(13,638)$ \\
\hline \multirow[t]{2}{*}{2007} & $0.264^{* * *}$ & $0.596^{* * *}$ & $185,614^{* * *}$ & $229,523^{* * *}$ \\
\hline & $(0.0223)$ & $(0.0553)$ & $(18,851)$ & $(44,622)$ \\
\hline Observations & 8,198 & 2,681 & 8,363 & 2,804 \\
\hline Adj. R-squared & 0.157 & 0.280 & 0.179 & 0.290 \\
\hline
\end{tabular}

All specifications include sector and year dummies as control variables Robust standard errors in parentheses ${ }^{*} p<0.1,{ }^{* *} p<0.05,{ }^{* * *} p<0.01$

indicator that minimum wages actually work for those targeted: formal full-time workers earning less than an amount considered necessary to fulfill basic needs. When restricting the sample to informal full-time workers, the coefficients on minimum wages remain positive for all but two specifications but not significant at any usual significance level. Thus, minimum wages do not appear to affect informal sector wages.

This stands in contrast with Welch's prediction that informal wages are pushed down by displaced formal sector workers who migrate to the informal sector. Yet, it also suggests that there are no positive spillover effects of minimum wages on the informal sector. Such spillover effects have been reported in other studies for different countries (Fajnzylber 2001 and Lemos 2004a for Brazil; Maloney \& Nuñez Mendez 2004 for several Latin American countries). Our results are, however, in line with Chun \& Khor (2010) for Indonesia. These findings suggest that the possibility of spillover effects cannot be easily generalized. The findings for the average effects on formal sector wages are in line with previous studies (for example, Del Carpio et al. 2012, Pratomo 2012 and The World Bank 2010) who report wage elasticities between 0.1 and 0.3. Combining this elasticity with actual changes in real wages and the minimum wage demonstrates the economic relevance of the minimum wage policy. We multiply the minimum wage 
Table 5 Wage regression using fixed effects for informal workers

\begin{tabular}{|c|c|c|c|c|c|c|c|c|}
\hline & (1) & (2) & (3) & (4) & (5) & (6) & (7) & (8) \\
\hline VARIABLES & $\log$ & $\begin{array}{l}\text { log- } \\
\text { below }\end{array}$ & level & $\begin{array}{l}\text { level- } \\
\text { below }\end{array}$ & $\begin{array}{l}\text { imput1 - } \\
\text { log }\end{array}$ & $\begin{array}{l}\text { imput1 - } \\
\text { level }\end{array}$ & $\begin{array}{l}\text { imput2 - } \\
\text { log }\end{array}$ & $\begin{array}{l}\text { imput2 - } \\
\text { level }\end{array}$ \\
\hline \multirow[t]{2}{*}{$\log M W$} & -0.0783 & 0.000858 & & & 0.0103 & & 0.0662 & \\
\hline & $(0.144)$ & $(0.188)$ & & & $(0.112)$ & & $(0.116)$ & \\
\hline \multirow[t]{2}{*}{ mw_real } & & & 0.0350 & -0.00435 & & 0.0404 & & 0.0885 \\
\hline & & & $(0.133)$ & $(0.122)$ & & $(0.129)$ & & $(0.129)$ \\
\hline \multirow{2}{*}{$\begin{array}{l}\text { log prov. } \\
\text { GDP }\end{array}$} & 0.0672 & $0.507^{* * *}$ & $-28,620$ & 18,473 & $0.183^{*}$ & $-15,780$ & $0.245^{*}$ & $-12,600$ \\
\hline & $(0.139)$ & $(0.181)$ & $(56,578)$ & $(35,190)$ & $(0.110)$ & $(57,191)$ & $(0.130)$ & $(63,387)$ \\
\hline \multirow{2}{*}{$\begin{array}{l}\text { elementary } \\
\text { school }\end{array}$} & 0.0987 & 0.0506 & 35,435 & 13,560 & $0.147^{* *}$ & 37,007 & $0.190^{* * *}$ & 43,596 \\
\hline & $(0.0900)$ & $(0.138)$ & $(34,093)$ & $(37,148)$ & $(0.0727)$ & $(33,335)$ & $(0.0737)$ & $(32,762)$ \\
\hline \multirow{2}{*}{$\begin{array}{l}\text { middle } \\
\text { school }\end{array}$} & 0.177 & 0.0700 & 81,602 & $-34,290$ & $0.217^{* *}$ & 88,548 & $0.285^{* * *}$ & $91,396^{*}$ \\
\hline & $(0.109)$ & $(0.191)$ & $(55,033)$ & $(52,324)$ & $(0.0908)$ & $(53,894)$ & $(0.0986)$ & $(53,684)$ \\
\hline \multirow{2}{*}{$\begin{array}{l}\text { high } \\
\text { school }\end{array}$} & 0.0156 & 0.0723 & $-1,189$ & $-38,783$ & 0.0745 & 2,016 & 0.181 & $-3,244$ \\
\hline & $(0.146)$ & $(0.270)$ & $(79,943)$ & $(69,140)$ & $(0.127)$ & $(77,600)$ & $(0.131)$ & $(77,141)$ \\
\hline \multirow{2}{*}{$\begin{array}{l}\text { higher } \\
\text { educ }\end{array}$} & $-0.370^{*}$ & & $-241,641$ & 370,537 & -0.127 & $-212,580$ & 0.00932 & $-203,802$ \\
\hline & $(0.196)$ & & $(212,687)$ & $(617,743)$ & $(0.186)$ & $(189,403)$ & $(0.184)$ & $(183,038)$ \\
\hline \multirow[t]{2}{*}{ urban } & 0.122 & -0.0149 & 31,721 & $-45,598$ & 0.0905 & 53,139 & $0.111^{*}$ & $70,090^{* *}$ \\
\hline & $(0.0787)$ & $(0.107)$ & $(36,028)$ & $(28,219)$ & $(0.0610)$ & $(35,309)$ & $(0.0643)$ & $(35,625)$ \\
\hline \multirow[t]{2}{*}{2000} & 0.00499 & $0.379^{* * *}$ & 14,059 & $113,461^{* * *}$ & 0.000133 & 5,061 & -0.00570 & 7,032 \\
\hline & $(0.0445)$ & $(0.0608)$ & $(14,077)$ & $(13,039)$ & $(0.0348)$ & $(13,676)$ & $(0.0367)$ & $(13,653)$ \\
\hline \multirow[t]{2}{*}{2007} & $0.109^{*}$ & $0.499^{* * *}$ & $51,692^{* *}$ & $194,993^{* * *}$ & 0.0294 & 38,846 & -0.0163 & 31,215 \\
\hline & $(0.0599)$ & $(0.0746)$ & $(26,132)$ & $(18,288)$ & $(0.0479)$ & $(26,020)$ & $(0.0531)$ & $(27,571)$ \\
\hline Observations & 5,611 & 3,036 & 7,785 & 4,942 & 6,941 & 7,785 & 6,803 & 7,785 \\
\hline $\begin{array}{l}\text { Adj. } \\
\text { R-squared }\end{array}$ & 0.011 & 0.122 & 0.013 & 0.100 & 0.010 & 0.011 & 0.017 & 0.013 \\
\hline
\end{tabular}

All specifications include sector and year dummies as control variables Robust standard errors in parentheses

${ }^{*} p<0.1,{ }^{* *} p<0.05,{ }^{* * *} p<0.01$

coefficient with the total change in real minimum wages and relate it to the total change in formal sector real wages between 2000 and 2007 (post Asian crisis):

$$
\frac{\beta_{M W} \times \Delta M W}{\Delta \text { real wage }}
$$

In this period, the average real minimum wage increased by $49.14 \%$, while the average real wage increased by $45.14 \%$. With the coefficient (0.178) from Table 4, column (1), this yields a contribution of the real minimum wage of about $19.38 \%$ to the increase in average formal sector wages.

\subsection{Employment effects}

We now turn to the employment effects. Table 6 presents the results from the LPM model with fixed effects as well as from the conditional logit fixed effects model. ${ }^{18} \mathrm{We}$ 
Table 6 Employment regression

\begin{tabular}{|c|c|c|c|c|c|c|c|c|}
\hline VARIABLES & $\begin{array}{l}\text { (1) } \\
\text { within } \\
\text { works }\end{array}$ & $\begin{array}{l}\text { (2) } \\
\text { clogit } \\
\text { works }\end{array}$ & $\begin{array}{l}\text { (3) } \\
\text { within } \\
\text { formal }\end{array}$ & $\begin{array}{l}\text { (4) } \\
\text { clogit } \\
\text { formal }\end{array}$ & $\begin{array}{l}(5) \\
\text { within } \\
\text { informal }\end{array}$ & $\begin{array}{l}\text { (6) } \\
\text { clogit } \\
\text { informal }\end{array}$ & $\begin{array}{l}\text { (7) } \\
\text { hybrid } \\
\text { informal vs } \\
\text { formal }\end{array}$ & $\begin{array}{l}\text { (8) } \\
\text { hybrid } \\
\text { informal vs } \\
\text { not working }\end{array}$ \\
\hline \multirow[t]{2}{*}{$\log M W$} & 0.0108 & 0.231 & $0.0597^{* * *}$ & $0.299 * *$ & $-0.0490^{* * *}$ & $-0.438^{* * *}$ & $0.322^{* * *}$ & $0.367^{* * *}$ \\
\hline & $(0.0156)$ & $(0.148)$ & $(0.0156)$ & $(0.147)$ & $(0.0176)$ & $(0.136)$ & $(0.0951)$ & $(0.114)$ \\
\hline \multirow{2}{*}{$\begin{array}{l}\text { log prov. } \\
\text { GDP }\end{array}$} & $0.0425^{* * *}$ & $0.329^{* * *}$ & $0.0708^{* * *}$ & $0.498^{* * *}$ & $-0.0283^{*}$ & $-0.307^{* * *}$ & $0.317^{* * *}$ & -0.0700 \\
\hline & $(0.0137)$ & $(0.117)$ & $(0.0145)$ & $(0.101)$ & $(0.0145)$ & $(0.110)$ & $(0.0831)$ & $(0.0992)$ \\
\hline \multirow{2}{*}{$\begin{array}{l}\text { elementary } \\
\text { school }\end{array}$} & 0.00646 & 0.0871 & -0.00533 & -0.0679 & 0.0118 & 0.0726 & -0.0383 & -0.0640 \\
\hline & $(0.0106)$ & $(0.121)$ & $(0.0115)$ & $(0.105)$ & $(0.0133)$ & $(0.0972)$ & $(0.0703)$ & $(0.0833)$ \\
\hline \multirow{2}{*}{$\begin{array}{l}\text { middle } \\
\text { school }\end{array}$} & -0.0175 & -0.149 & 0.00136 & 0.00108 & -0.0189 & -0.148 & 0.0441 & 0.138 \\
\hline & $(0.0164)$ & $(0.166)$ & $(0.0170)$ & $(0.155)$ & (0.0196) & $(0.138)$ & $(0.100)$ & $(0.124)$ \\
\hline \multirow{2}{*}{$\begin{array}{l}\text { high } \\
\text { school }\end{array}$} & -0.0336 & -0.215 & 0.0131 & 0.125 & $-0.0468^{*}$ & -0.287 & 0.165 & 0.270 \\
\hline & $(0.0209)$ & $(0.213)$ & $(0.0216)$ & $(0.213)$ & $(0.0244)$ & $(0.187)$ & $(0.121)$ & $(0.164)$ \\
\hline \multirow{2}{*}{$\begin{array}{l}\text { higher } \\
\text { educ }\end{array}$} & -0.0136 & 0.372 & $0.150^{* * *}$ & $1.590^{* * *}$ & $-0.163^{* * *}$ & $-1.003^{* * *}$ & $0.838^{* * *}$ & 0.325 \\
\hline & $(0.0281)$ & $(0.336)$ & $(0.0316)$ & $(0.341)$ & $(0.0312)$ & $(0.365)$ & $(0.167)$ & $(0.240)$ \\
\hline \multirow[t]{2}{*}{ urban } & $0.0214^{* *}$ & $0.207^{* *}$ & $0.0328^{* * *}$ & $0.240^{* * *}$ & -0.0114 & -0.0636 & $0.175^{* * *}$ & -0.0840 \\
\hline & $(0.00972)$ & $(0.0861)$ & $(0.00971)$ & $(0.0818)$ & $(0.0105)$ & $(0.0795)$ & $(0.0553)$ & $(0.0696)$ \\
\hline \multirow[t]{2}{*}{2000} & $0.0871^{* * *}$ & $0.893^{* * *}$ & 0.00754 & -0.0105 & $0.0796^{* * *}$ & $0.608^{* * *}$ & $-0.173^{* * *}$ & $-0.526^{* * *}$ \\
\hline & $(0.00508)$ & $(0.0502)$ & $(0.00517)$ & $(0.0486)$ & (0.00573) & $(0.0450)$ & $(0.0310)$ & $(0.0372)$ \\
\hline \multirow[t]{2}{*}{2007} & $0.0950^{* * *}$ & $0.950^{* * *}$ & $-0.143^{* * *}$ & $-1.239 * * *$ & $0.238^{* * *}$ & $1.797^{* * *}$ & $-1.120^{* * *}$ & $-1.146^{* * *}$ \\
\hline & $(0.00662)$ & $(0.0606)$ & $(0.00685)$ & $(0.0573)$ & $(0.00721)$ & $(0.0581)$ & $(0.0398)$ & $(0.0470)$ \\
\hline Observations & 48,030 & 14,202 & 48,030 & 14,405 & 48,030 & 18,853 & 48,030 & 48,030 \\
\hline $\begin{array}{l}\text { Adj. } \\
\text { R-squared }\end{array}$ & 0.039 & & 0.033 & & 0.076 & & & \\
\hline
\end{tabular}

All specifications include child, elderly, and year dummies as control variables

For the hybrid model, variables are deviations from the individual's mean of this specific variable

Robust standard errors in parentheses

${ }^{*} p<0.1,{ }^{* *} p<0.05,{ }^{* * *} p<0.01$

analyze the probabilities of having any job and of being employed in the formal sector or informal sector: "formal" (column 3,4) measures the probability of having a formal sector job compared to being unemployed or having an informal sector job, while "informal" (column 5, 6) measures the probability of being employed in the informal sector compared to being unemployed or employed in the formal sector. Being employed in the formal sector or informal sector is significantly associated with higher education and provincial GDP growth. Compared to those without education, individuals with higher education are more (less) likely to have a job in the formal (informal) sector. Growth drives overall and formal sector job creation.

According to the theory, increases in minimum wages should negatively affect formal employment and could force displaced formal sector workers into informality. Remarkably, all of the minimum wage coefficients are positive for overall employment, positive 
and statistically significant for formal employment and negative and statistically significant for informal employment. The coefficient suggests that a ten percent increase in minimum wages increases (decrease) the probability of having a formal (informal) sector job by 0.597 (0.490) percentage points, holding other variables constant. Interpreting the coefficients of the fixed effects conditional logit model suggests that if the log of minimum wage increases by one unit ( 2.7 times), an individual's odds of having a formal sector job are multiplied by $e^{0.299}=1.35$, i.e., the odds increase, and the odds of having an informal sector job by $e^{-0.438}=0.65$, i.e., the odds decrease.

Although the coefficients of the minimum wage are rather small (smaller than 1 percentage point for a $10 \%$ increase in minimum wage), they are of economic relevance as they are positive for formal employment and hence contradict the traditional theory of a dualistic labor market. The positive sign suggests that more workers find their way from outside the labor force or from the informal sector into the formal sector. That is, for this dataset an increase in minimum wages does not lead to a reduction in employment overall and particularly not in the formal sector during the analyzed period in Indonesia.

The hybrid model in column 7 and 8 uses informal employment as base category and examines if the decrease in informal employment is due to individuals becoming unemployed or migrating to the formal sector. The coefficients are for both cases positive and similar in size. This confirms the result from above that the odds of being informally employed decrease. Compared to having an informal sector job, both the odds of being formally employed and the odds of being unemployed increase by almost the same order of magnitude.

These results are in line with Comola \& de Mello (2011) and The World Bank (2010), who do not find negative effects on overall employment. However, these studies find that minimum wages increase informality and cause job losses in the formal sector. Negative employment effects in the formal sector are also found in most studies on Indonesia that analyze formal employment by using aggregate data (e.g., Rama 2001, Suryahadi et al. 2003, and Del Carpio et al. 2012). Our results are also different from those obtained by Chun \& Khor (2010), who find negative effects on the probability of being formally employed on an individual level. One study that also finds positive effects on formal employment is Magruder (2013). According to the author, positive minimum wage effects on formal employment can be explained by higher wages causing higher local expenditures, which eventually lead to a higher labor demand in local (below province level) industries.

Which other explanations are possible? First, one reason why our results differ from the most recent studies in terms of formal employment effects may be the time period. As seen in Section 3, minimum wages drastically increased and doubled in real terms during the first half of the 1990s. However, during the period we have analyzed, though the minimum wage level was still relatively high, its change was more moderate. The rise in labor cost might have been small in relation to the firms' overall cost, thus not requiring the displacement of workers. Second, a branch of the minimum wage literature tries to explain positive or employment effects around zero by proposing different channels of adjustment in the employer's and workers' behavior that are not incorporated in the traditional model. Such channels include, for example, on the employer's side, a reduction of nonwage benefits, training, profit or turnover, and a rise in prices or efficiency through tighter human resource practices, while workers might increase working effort in response to a 
rise in wages (see Schmitt 2013, 15ff. for a good overview). Hirsch et al. (2015) tested those channels empirically for a sample of U.S. quick-service restaurants and found that the increase in labor costs by a higher minimum wage is mainly absorbed by higher performance standards, a lower number of turnover, a rise in prices, reduced profit margins, and wage cuts of highly paid workers. It is possible that some of these channels of adjustment also apply to firms in developing countries.

\subsection{Robustness checks}

Though we argued that there is no endogeneity in form of reverse causality due to using wages on an individual level, simultaneity bias might be a problem. Local economic shocks, for example a large-scale infrastructure project or a new factory, can obviously have an impact on wages and employment through the labour market. At the same time, such shocks are likely - in an earlier stage - to influence expectations of local economic performance and hence the setting of the minimum wage. To address this possible bias, we therefore implement an IV estimator using two-lagged provincial GDP as an instrument. The results are presented in the (Appendix: Table 9 for the wage regression and in Table 10 for employment). For the wage regression, the minimum wage coefficient for all workers and the formal sector stay statistically significant and Ipositive. In the employment regression the minimum wage coefficient for formal sector workers now turns negative, but none of the coefficients is statistically significant. Therefore, even though positive employment effects are not robust to our IV regression, we still do not find statistically significant negative effects. We should note, however, that the F statistics of the first stage of the IV regression suggest only limited relevance of our instrument.

\section{Conclusion}

This article studies the effects of minimum wages on employment and wages in Indonesia between 1997 and 2007. The case of Indonesia is particularly interesting as minimum wages are annually adjusted, considered as relatively high and do not cover a large informal sector. Using the theoretical framework of a dualistic labor market model, we examine whether minimum wages do increase formal sector wages and decrease formal employment. Furthermore, this paper analyzes if there are spillover effects of minimum wages on the informal sector. For this purpose, we exploit the second, third, and fourth panel waves of the IFLS, which has the major advantage of providing information on informal sector wages. Moreover, using its individual data bypasses the endogeneity bias that may occur when aggregate data on a provincial level is used as minimum wages are set at a provincial level, thus taking local labor markets into account.

Estimating a fixed effects model for workers that remained full-time workers in at least two adjacent survey waves shows that minimum wages have a positive and significant effect on formal sector wages. However, we do not find any significant effect on informal sector wages. As the working poor tend to be employed in the informal sector, the efficacy of minimum wages as a poverty alleviation tool is thus limited. Regarding employment, our results contradict the dualistic labor market model as we find statistically significant, small positive effects on formal employment when 
applying both a linear probability model with fixed effects and a fixed effects conditional logit model.

There are three possible explanations for these findings. Firstly, minimum wage increases in real terms might have been too low between 1997 and 2007 to provoke overall negative employment effects. Secondly, employers might use adjustment channels other than employment to deal with the increase in labor costs. Thirdly, more aggregate effects related to the minimum wage might outweigh possible negative employment effects. As we do control for macroeconomic effects on a provincial and state level, we suggest that those effects may be looked for on a local or district level. Especially higher minimum wages as a local demand stimulus seems plausible (see Magruder 2013).

Our results may be taken as encouragement to foster compliance with minimum wages. This can be reached by better monitoring, higher fines for cheating, or providing incentives such as tax relief for firms that comply with the law. In addition, as the rise in real minimum wages between 1997 and 2007 was relatively mild, it seems reasonable to maintain this general policy of moderate - but above inflationgrowth rates. Lastly, the relatively small contribution of the real minimum wage increase to the increase in formal sector wages indicates that minimum wages can benefit formal sector workers but are not a substitute for a growing economy or investments in education that tend to increase workers' wages and welfare also in the informal sector.

Obviously, these results cover only one country during a limited time period and are not easily transferable to other contexts. However, they indicate that minimum wages under certain circumstances do not lower formal sector employment. To determine these circumstances is exactly what future research should add to the current debate on minimum wages.

\section{Endnotes}

${ }^{1}$ See, for example, Borjas (2002) for a review of the traditional model of minimum wages in a competitive labor market.

${ }^{2}$ We acknowledge that informality has different dimensions related either to the character of the firm (or productive unit), for example, whether the firm is registered and pays taxes, or to employment, for example, whether a worker has a work contract and enjoys social protection. Yet, for ease of exposition, we will use the terms formal and informal as synonyms for the covered and uncovered sector, respectively. Details on how we empirically define informal employment in our data are given below.

${ }^{3}$ Even in the formal (or covered) sector, however, compliance may not be perfect. How (partial) non-compliance can arise is shown by Basu et al. (2010) in a model with endogenous levels of enforcement.

${ }^{4}$ In line with the literature, we refer to a minimum wage that is higher than the market clearing wage as "binding", so that it is expected to affect the wage distribution and employment. "Compliance" is the degree employers pay wages according to the policy, and "enforcement" describes whether compliance with the minimum wages will be monitored and if non-compliance will be sufficiently sanctioned to lower incentives to employers to cheat (Jones 1997). 
${ }^{5}$ The minimum physical needs or Kebutuhan Fisik Minimum (KFM) are represented by a consumption bundle including food, fuel, housing, clothing, and other items which are considered to be essential for a single worker. In 1996, this item list was extended and is now referred to as substantial needs or Kebutuhan Hidup Minimum (KHM)(Suryahadi et al. 2003).

${ }^{6}$ Activities other than work include job searching, housekeeping, being sick, retired, on vacation.

${ }^{7}$ In IFLS 4 two new categories for working status appear namely "casual workers in agriculture" and "casual worker not in agriculture" which we also treat as informal workers.

${ }^{8}$ This is in line with previous minimum wage studies on Indonesia, such as Comola \& de Mello (2011).

${ }^{9}$ Of course, selection into full-time employment might still introduce some biases into our analysis.

${ }^{10}$ The Indonesian National Statistical Office (BPS) provided data on minimum wages, provincial GDP and Consumer Price Index (CPI), which we used to deflate nominal wages and nominal minimum wages. The BPS constructs the CPI for 44 different cities across the country. We matched the city CPIs to their corresponding province, taking the average if there is more than one city listed per province. In doing so, we created a CPI measure on a provincial level. The CPI's are converted to the base year 2002. The mean of nominal minimum wages is constructed by taking the average of nominal minimum wages of the 13 original IFLS 1 provinces. The average of real minimum wages is the mean of provincial nominal minimum wages deflated by the provincial CPI. In each year, the subpopulation of full-time workers do not include the top and the bottom percentile to avoid that descriptive statistics are driven by outliers, especially in the top one percent.

${ }^{11}$ Though students are generally not included when analyzing employment status, we included those students who also reported to be full-time workers in the wage analysis.

${ }^{12}$ In fact, they find that the minimum wage plays a significant role in the decrease of inequality.

${ }^{13}$ Real minimum wages in 2000 were lower than in 1997.

${ }^{14}$ We adopted this strategy from Alaniz et al. (2011), who study the impact of Nicaragua's various sectoral minimum wages.

${ }^{15}$ see for example Söderbom et al. (2005) and Boyce (2010)

${ }^{16}$ Except sector dummies which are not included as they do not exist for inactive individuals.

${ }^{17}$ Basically, one tries to find a statistic $s_{i}$ which is sufficient for $a_{i}$ so that the likelihood contribution of one unit does not depend anymore on $a_{i}$. In the case that there is such a statistic, one can maximize the conditional likelihood function and get consistent estimates. Such statistics exists for the logit model in the case that units change their outcomes (see, e.g., Chamberlain 1980; additionally, Verbeek 2012 gives a good overview). We used the clogit command in Stata.

${ }^{18} \mathrm{We}$ added additional estimation results for our most important specifications separated by male and female to the (Appendix: Tables 7 and 8). Female workers seem to benefit less from minimum wages as their coefficients for wages of all full-time workers, overall and formal employment are not statistically significant, but they are still positive. 


\section{Appendix}

Table 7 Wage regression by gender

\begin{tabular}{|c|c|c|c|c|c|c|}
\hline VARIABLES & $\begin{array}{l}(1) \\
\text { all male }\end{array}$ & $\begin{array}{l}\text { (2) } \\
\text { all female }\end{array}$ & $\begin{array}{l}\text { (3) } \\
\text { formal male }\end{array}$ & $\begin{array}{l}(4) \\
\text { formal female }\end{array}$ & $\begin{array}{l}(5) \\
\text { informal male }\end{array}$ & $\begin{array}{l}\text { (6) } \\
\text { informal female }\end{array}$ \\
\hline \multirow[t]{2}{*}{ mw_real } & $0.364^{* * *}$ & 0.198 & $0.429^{* * *}$ & $0.430^{* *}$ & -0.0119 & 0.182 \\
\hline & $(0.0935)$ & $(0.123)$ & $(0.135)$ & $(0.185)$ & $(0.180)$ & $(0.187)$ \\
\hline \multirow[t]{2}{*}{ log prov. GDP } & $-10,559$ & 25,412 & 12,944 & $-59,354$ & $-119,653$ & $135,370^{* *}$ \\
\hline & $(33,273)$ & $(54,842)$ & $(44,582)$ & $(108,053)$ & $(77,424)$ & $(68,850)$ \\
\hline \multirow[t]{2}{*}{ elementary school } & $-9,340$ & $62,599 *$ & 12,250 & 13,615 & $-9,836$ & $97,296^{* *}$ \\
\hline & $(24,406)$ & $(32,404)$ & $(31,463)$ & $(30,338)$ & $(45,659)$ & $(48,811)$ \\
\hline \multirow[t]{2}{*}{ middle school } & 32,941 & 6,384 & 37,459 & $-135,441^{* *}$ & 64,840 & 97,375 \\
\hline & $(37,702)$ & $(50,122)$ & $(50,280)$ & $(61,571)$ & $(73,103)$ & $(76,952)$ \\
\hline \multirow[t]{2}{*}{ high school } & $83,852^{*}$ & 4,668 & $137,560^{* *}$ & 24,104 & $-13,539$ & $-40,304$ \\
\hline & $(48,208)$ & $(72,109)$ & $(62,512)$ & $(65,104)$ & $(100,440)$ & $(127,959)$ \\
\hline \multirow[t]{2}{*}{ higher educ } & $327,807^{* * *}$ & $260,809^{* *}$ & $456,327^{* * *}$ & $310,723^{* * *}$ & $-131,766$ & $-612,339^{*}$ \\
\hline & $(90,829)$ & $(111,187)$ & $(99,933)$ & $(95,923)$ & $(257,097)$ & $(348,720)$ \\
\hline \multirow[t]{2}{*}{ urban } & $82,231^{* * *}$ & 13,996 & $74,081^{* * *}$ & 27,409 & 87,920 & $-39,262$ \\
\hline & $(23,303)$ & $(21,140)$ & $(27,778)$ & $(29,267)$ & $(54,548)$ & $(36,470)$ \\
\hline \multirow[t]{2}{*}{2000} & 15,588 & 414.9 & $-4,682$ & 27,346 & $32,460^{*}$ & $-4,282$ \\
\hline & $(10,328)$ & $(12,875)$ & $(13,856)$ & $(17,819)$ & $(19,300)$ & $(19,739)$ \\
\hline \multirow[t]{2}{*}{2007} & $98,074^{* * *}$ & $58,873^{* *}$ & $177,618^{* * *}$ & $214,831^{* * *}$ & $117,917^{* * *}$ & $-60,658^{*}$ \\
\hline & $(15,498)$ & $(24,322)$ & $(20,664)$ & $(45,627)$ & $(36,170)$ & $(32,020)$ \\
\hline Observations & 13,371 & 6,246 & 6,038 & 2,325 & 4,648 & 3,137 \\
\hline Adj. R-squared & 0.056 & 0.039 & 0.165 & 0.249 & 0.022 & 0.020 \\
\hline
\end{tabular}

All specifications include sector and year dummies as control variables and use level of real wage as dependent variable Robust standard errors in parentheses

${ }^{*} p<0.1,{ }^{* *} p<0.05,{ }^{* * *} p<0.01$ 
Table 8 Employment regression by gender

\begin{tabular}{|c|c|c|c|c|c|c|}
\hline VARIABLES & $\begin{array}{l}(1) \\
\text { male } \\
\text { works }\end{array}$ & $\begin{array}{l}\text { (2) } \\
\text { female } \\
\text { works }\end{array}$ & $\begin{array}{l}(3) \\
\text { male } \\
\text { formal }\end{array}$ & $\begin{array}{l}\text { (4) } \\
\text { female } \\
\text { formal }\end{array}$ & $\begin{array}{l}(5) \\
\text { male } \\
\text { informal }\end{array}$ & $\begin{array}{l}\text { (6) } \\
\text { female } \\
\text { informal }\end{array}$ \\
\hline \multirow[t]{2}{*}{$\log M W$} & 0.0124 & 0.0107 & $0.0959^{* * *}$ & 0.0291 & $-0.0835^{* * *}$ & -0.0184 \\
\hline & $(0.0155)$ & $(0.0251)$ & $(0.0262)$ & $(0.0182)$ & $(0.0256)$ & $(0.0241)$ \\
\hline \multirow[t]{2}{*}{ log prov. GDP } & $0.0302^{* *}$ & $0.0564^{* *}$ & $0.0739^{* * *}$ & $0.0706^{* * *}$ & $-0.0437^{* *}$ & -0.0142 \\
\hline & $(0.0141)$ & $(0.0225)$ & $(0.0219)$ & $(0.0191)$ & $(0.0201)$ & $(0.0208)$ \\
\hline \multirow[t]{2}{*}{ elementary school } & -0.00383 & 0.0188 & -0.00177 & -0.00711 & -0.00206 & 0.0259 \\
\hline & $(0.00900)$ & $(0.0192)$ & $(0.0183)$ & $(0.0135)$ & $(0.0184)$ & $(0.0191)$ \\
\hline \multirow[t]{2}{*}{ middle school } & -0.00229 & -0.0311 & 0.0168 & -0.0159 & -0.0191 & -0.0152 \\
\hline & $(0.0147)$ & $(0.0293)$ & $(0.0274)$ & $(0.0194)$ & $(0.0266)$ & $(0.0288)$ \\
\hline \multirow[t]{2}{*}{ high school } & 0.00196 & $-0.0745^{* *}$ & $0.0555^{*}$ & -0.0315 & $-0.0535^{*}$ & -0.0431 \\
\hline & $(0.0200)$ & $(0.0380)$ & $(0.0335)$ & $(0.0254)$ & $(0.0322)$ & $(0.0369)$ \\
\hline \multirow[t]{2}{*}{ higher educ } & 0.0472 & -0.0729 & $0.184^{* * *}$ & $0.127^{* * *}$ & $-0.136^{* * *}$ & $-0.200^{* * *}$ \\
\hline & $(0.0300)$ & $(0.0492)$ & $(0.0477)$ & $(0.0403)$ & $(0.0443)$ & $(0.0428)$ \\
\hline \multirow[t]{2}{*}{ urban } & 0.0110 & $0.0291^{*}$ & $0.0317^{* *}$ & $0.0344^{* * *}$ & -0.0208 & -0.00524 \\
\hline & $(0.0101)$ & $(0.0156)$ & $(0.0156)$ & $(0.0120)$ & $(0.0148)$ & $(0.0148)$ \\
\hline \multirow[t]{2}{*}{2000} & $0.0448^{* * *}$ & $0.123^{* * *}$ & 0.000249 & $0.0134^{* *}$ & $0.0446^{* * *}$ & $0.110^{* * *}$ \\
\hline & $(0.00521)$ & $(0.00814)$ & $(0.00858)$ & $(0.00616)$ & $(0.00834)$ & $(0.00785)$ \\
\hline \multirow[t]{2}{*}{2007} & $0.0560^{* * *}$ & $0.125^{* * *}$ & $-0.202^{* * *}$ & $-0.0952^{* * *}$ & $0.258^{* * *}$ & $0.220^{* * *}$ \\
\hline & $(0.00688)$ & $(0.0107)$ & $(0.0109)$ & $(0.00857)$ & $(0.0103)$ & $(0.0100)$ \\
\hline Observations & 22,217 & 25,813 & 22,217 & 25,813 & 22,217 & 25,813 \\
\hline Adj. R-squared & 0.031 & 0.068 & 0.049 & 0.032 & 0.086 & 0.078 \\
\hline
\end{tabular}

All specifications include child, elderly, and year dummies as control variable Linear Probability Model includes FE

Robust standard errors in parentheses

${ }^{*} p<0.1,{ }^{* *} p<0.05,{ }^{* * *} p<0.01$ 
Table 9 Wage Regression (IV)

\begin{tabular}{|c|c|c|c|}
\hline & $(1)$ & $(2)$ & (3) \\
\hline VARIABLES & all & formal & informal \\
\hline \multirow[t]{2}{*}{$\log M W$} & 0.0588 & -0.167 & 0.226 \\
\hline & $(0.150)$ & $(0.152)$ & $(0.170)$ \\
\hline \multirow[t]{2}{*}{ log prov. GDP } & $0.0390^{* *}$ & $0.0876^{* * *}$ & $-0.0487^{* * *}$ \\
\hline & $(0.0164)$ & $(0.0166)$ & $(0.0186)$ \\
\hline \multirow[t]{2}{*}{ elementary school } & 0.00682 & -0.00701 & 0.0138 \\
\hline & $(0.0116)$ & $(0.0118)$ & $(0.0132)$ \\
\hline \multirow[t]{2}{*}{ middle school } & -0.0171 & -0.000881 & -0.0162 \\
\hline & $(0.0167)$ & $(0.0169)$ & $(0.0189)$ \\
\hline \multirow[t]{2}{*}{ high school } & -0.0336 & 0.0130 & $-0.0466^{*}$ \\
\hline & $(0.0216)$ & $(0.0219)$ & $(0.0245)$ \\
\hline \multirow[t]{2}{*}{ higher educ } & -0.0140 & $0.151^{* * *}$ & $-0.165^{* * *}$ \\
\hline & $(0.0309)$ & $(0.0313)$ & $(0.0350)$ \\
\hline \multirow[t]{2}{*}{ urban } & $0.0210^{* *}$ & $0.0345^{* * *}$ & -0.0135 \\
\hline & $(0.00892)$ & $(0.00905)$ & $(0.0101)$ \\
\hline \multirow[t]{2}{*}{2000} & $0.0979^{* * *}$ & -0.0435 & $0.141^{* * *}$ \\
\hline & $(0.0339)$ & $(0.0343)$ & $(0.0384)$ \\
\hline \multirow[t]{2}{*}{2007} & $0.0873^{* * *}$ & $-0.106^{* * *}$ & $0.194^{* * *}$ \\
\hline & $(0.0247)$ & $(0.0250)$ & $(0.0280)$ \\
\hline Observations & 48,030 & 48,030 & 48,030 \\
\hline
\end{tabular}

All specifications include sector and year dummies as control variables and use level of wage as dependent variable Standard errors in parentheses

${ }^{*} p<0.1,{ }^{* *} p<0.05,{ }^{* * *} p<0.01$

Table 10 Employment Regression (IV)

\begin{tabular}{llll}
\hline & $(1)$ & $(2)$ & $(3)$ \\
VARIABLES & all & formal & informal \\
\hline log MW & 0.0606 & -0.215 & 0.259 \\
log prov. GDP & $(0.150)$ & $(0.151)$ & $(0.245)$ \\
elementary school & $0.0430^{* * *}$ & $0.0887^{* * *}$ & $-0.0786^{* * *}$ \\
& $(0.0164)$ & $(0.0165)$ & $(0.0219)$ \\
middle school & 0.000350 & -0.00893 & 0.00194 \\
high school & $(0.0115)$ & $(0.0116)$ & $(0.0140)$ \\
& -0.0178 & -0.00854 & -0.000549 \\
higher educ & $(0.0166)$ & $(0.0167)$ & $(0.0208)$ \\
& -0.0287 & 0.00569 & -0.0356 \\
urban/rural & $(0.0214)$ & $(0.0215)$ & $(0.0268)$ \\
& -0.0255 & $0.123^{* * *}$ & $-0.129^{* * *}$ \\
Observations & $(0.0306)$ & $(0.0307)$ & $(0.0367)$ \\
\hline
\end{tabular}

All specifications include child, elderly, and year dummies as control variables Standard errors in parentheses

${ }^{*} p<0.1,{ }^{* *} p<0.05,{ }^{* * *} p<0.01$ 


\section{Competing interests}

The IZA Journal of Labor and Development is committed to the IZA Guiding Principles of Research Integrity. The authors declare that they have observed these principles.

\section{Authors' information}

M. Hohberg is a PhD student at University of Göttingen, Germany.

J. Lay is head of research program "Globalization and Development" at the GIGA German Institute of Global and Area Studies, Hamburg, and professor at the University of Göttingen, Germany.

\section{Acknowledgments}

The authors gratefully acknowledge the provision of the Indonesian Family Life Survey (IFLS) by the RAND Corporation as well as the provision of data on minimum wages and consumer price indices by Budan Pusat Statistik Indonesia (Statistics Indonesia). We thank an anonymous referee for a thorough review and valuable comments, which significantly contributed to improving the publication. We also appreciate comments and suggestions by Sebastian Renner on an earlier draft.

Responsible editor: Hartmut Lehmann.

Received: 20 January 2015 Accepted: 3 August 2015

Published online: 10 September 2015

\section{References}

Acemoglu D, Pischke JS (1999) The Structure of Wages and Investment in General Training. J Polit Econ 107:539-572

Al Jazeera (2013) Indonesian workers demand higher pay. http://www.aljazeera.com/news/asia-pacific/2013/02/ 20132675333828387.html. Accessed 30 Dec 2014

Alaniz E, Gindling T, Terrell K (2011) The impact of minimum wages on wages, work and poverty in Nicaragua. Labour Econ 18:\$45-\$59

Alatas V, Cameron LA (2008) The impact of minimum wages in employment in a low-income country: a quasi-natural experiment in Indonesia. ILR Review 61:201-223

Allison PD (2009) Fixed Effects Regression Models. SAGE Publications, Thousand Oaks

Basu A, Chau N, Kanbur R (2010) Turning a blind eye: Costly enforcement, credible commitment, and minimum wage laws. Econ J 120:244-269

Bhorat H, Kanbur R, Mayet N (2013) The impact of sectoral minimum wage laws on employment, wages, and hours of work in South Africa. IZAJOLD 2:1

Borjas GJ (2002) Labor Economics, 2nd (international) edn. Mc Graw Hill, Boston

Boyce CJ (2010) Understanding fixed effects in human well-being. J Econ Psychol 31:1-16

Cahuc P, Michel P (1996) Minimum wage unemployment and growth. Eur Eco Rev 40:1463-1482

Card D, Krueger A (1994) Minimum Wages and Employment: A case study of the Fast-Food Industry in New Jersey and Pennsylvania. Am Econ Rev 84:772-793

Chamberlain G (1980) Analysis of Covariance with Qualitative Data. Rev Econ Stud 47:225-238

Chun N, Khor N (2010) Minimum Wages and Changing Wage Inequality in Indonesia. ADB Economics Working Paper Series 196. Asian Development Bank, Manila

Comola M, de Mello L (2011) How does decentralized wage setting affect employment and informality? The case of Indonesia. Rev Income Wealth 57:S79-599

Cunningham W (2007) Minimum Wages and Social Policy: Lessons from Developing Countries. The World Bank, Washington D.C

Del Carpio X, Nguyen H, Wang LC (2012) Does the Minimum Wage Affect Employment? Evidence from the Manufacturing Sector in Indonesia. Policy Research Working Paper 6147. The World Bank, Washington D.C

Dickens R, Machin S, Manning A (1999) The Effects of Minimum Wages on Employment: Theory and Evidence from Britain. J Labor Econ 17:1-22

Dinkelman T, Ranchhod V (2012) Evidence on the impact of minimum wage laws in an informal sector: Domestic workers in South Africa. J Dev Econ 99:27-45

Fajnzylber P (2001) Minimum Wage Effects throughout the Wage Distribution: Evidence from Brazil's Formal and Informal Sectors. Texto para Discussão 151, Department of Economics and CEDEPLAR. Universidade Federal do Belo Horizonte, Belo Horizonte

Gindling T, Terrell K (2005) The Effect of Minimum Wages on Actual Wages in Formal and Informal Sectors in Costa Rica. World Dev 33:1905-1921

Gindling T, Terrell K (2007) The effects of multiple minimum wages throughout the labor market: The case of Costa Rica. Labour Econ 14:485-511

Gramlich EM (1976) Impact of Minimum Wages on Other Wages, Employment, and Family Incomes. Brookings Pap Econ Act 7:409-462

Harrison A, Scorse J (2010) Multinational and Anti-Sweatshop Activism. Am Econ Rev 100:247-273

Hertz T (2005) The Effect of Minimum Wages on the Employment and Earnings of South Africa's Domestic Service Workers. DPRU Working Paper 05/99. Development Policy Research Unit, Cape Town

Hirsch BT, Kaufman BE, Zelenska T (2015) Minimum Wage Channels of Adjustment. Ind Relat 54:199-239

International Labour Organisation (ILO) (2004) Act of the Republic of Indonesia Number 13 Year 2003. Unofficial translation prepared by ILO Jakarta, http://www.lo.org/dyn/travail/docs/760/Indonesian\%20Labour\%20Law\%20\%20Act\%2013\%20of\%202003.pdf. Accessed 10 March 2014

Islam I, Nazara S (2000) Minimum Wage and the Welfare of Indonesian Workers. Occasional Discussion Paper Series 3. International Labour Organization, Jakarta

Jones P (1997) The Impact of Minimum Wage Legislation in Developing Countries where Coverage is Incomplete. WPS 98-2, Centre for the Study of African Economies, University of Oxford 
Lemos S (2004a) The Effects of the Minimum Wage in the Formal and Informal Sectors in Brazil. IZA Discussion Paper 1089. Institute for the Study of Labor (IZA), Bonn

Lemos S (2004b) Minimum Wage Policy and Employment Effects: Evidence from Brazil. Economia 5:219-266

Lemos S (2009) Minimum Wage Effects in a Developing Country. Labour Econ 16:224-237

Lustig NC, McLeod D (1997) Minimum Wages and Poverty in Developing Countries: Some Empirical Evidence. In: Edwards S, Lustig NC (eds) Labor Markets in Latin America. Brookings Institution Press, Washington D.C., pp 62-103

Machin S, Manning A (1994) The Effects of Minimum Wages on Wage and Employment: Evidence from the U.K. Wages Councils. ILR Rev 47:319-329

Magruder JR (2013) Can minimum wages cause a big push? Evidence from Indonesia. J Dev Econ 100:48-62

Maloney W, Nuñez Mendez J (2004) Measuring the Impact of Minimum Wages: Evidence from Latin America. In: Pagés C, Heckman JJ (eds) Lessons from Latin America and the Caribbean. University of Chicago Press, Law and Employment, pp 109-130

Manning C (2003) Labor Policy and Employment Creation: An Emerging Crisis? Report Submitted to USAID/ECG 110, Jakarta

Mincer J (1976) Unemployment Effects of Minimum Wages. J Polit Econ 84:S87-S104

Neumark D, Schweitzer M, Wascher W (2004) The effects of minimum wages throughout the wage distribution. J Hum Resour 2:425-450

OECD (2015a) Earnings: Minimum wages relative to median wages (database), http://dx.doi.org/10.1787/data-00313-en. Accessed 11 Aug 2015

OECD (2015b) Real minimum wages (database), https://stats.oecd.org/Index.aspx?DataSetCode=RMW. Accessed 11 Aug 2015

Pratomo DS (2012) Minimum Wage Effects Throughout the Wage Distribution: Evidence from Indonesia. Eur J Econ Finance Admin Sci 2012:27-35

Purnomo H (2014) Indonesia Girds for Millions Protesting for Higher Wages. Bloomberg, online http:/www.bloomberg.com/ news/articles/2014-12-03/indonesia-girds-for-millions-demonstrating-for-higher-wage-gains. Accessed 30 Dec 2014

Rama M (2001) The Consequences of Doubling the Minimum Wage: The Case of Indonesia. ILR Rev 54:864-881

Saget C (2008) Fixing Minimum Wage Levels in Developing Countries: Common Failures and Remedies. Int Labour Rev $147: 25-42$

Schmitt J (2013) Why Does the Minimum Wage Have No Discernible Effect on Employment. Technical report, Center for Economic and Policy Research, Washington, D.C

Shapiro C, Stiglitz JE (1984) Equilibrium Unemployment as a Worker Discipline Device. Am Econ Rev 74:433-444

Söderbom M, Teal F, Wambugu A (2005) Unobserved heterogeneity and the relation between earnings and form size: evidence from two developing countries. Econ Lett 87:153-159

Stigler GJ (1946) The Economics of Minimum Wage Legislation. Am Econ Rev 36:358-365

Strauss J, Witoelar F, Sikoki B, Wattie AM (2009) The Fourth Wave of the Indonesia Family Life Survey: Overview and Field Report. Volume 1, RAND Labor and Population working paper series WR-675/1-NIA/NICHD, RAND.

Suryahadi A, Widyanti W, Perwira D, Sumarto S (2003) Minimum Wage Policy and its Impact on Employment in the Urban Formal Sector. Bull Indones Econ Stud 39:29-50

The World Bank (2010) Indonesia Jobs Report: Towards Better Jobs and Security for All. Jakarta Vaswani K (2013) Indonesia's wage wars. BBC. http://www.bbc.co.uk/news/business-21840416. Accessed 30 Dec 2014. Verbeek M (2012) A Guide to Modern Econometrics, 4th edn. Wiley, Chichester

Wage Indicator Network (2015), 'Minimum Wages in Indonesia with effect from 01-01-2015 to 31-12-2015. Available online http://www.wageindicator.org/main/salary/minimum-wage/indonesia, last checked 26/07/2015

Welch F (1974) Minimum Wage Legislation in the United States. Econ Inq 12:285-318

Widarti D (2006) Role of Minimum Wage in Informal Wage Determination in Indonesia. Technical report, International Labour Organization, Jakarta

\section{Submit your manuscript to a SpringerOpen ${ }^{\circ}$ journal and benefit from:}

- Convenient online submission

- Rigorous peer review

- Immediate publication on acceptance

- Open access: articles freely available online

- High visibility within the field

- Retaining the copyright to your article 